\title{
PENGARUH BAHASA ARAB TERHADAP PERKEMBANGAN BAHASA INDONESIA
}

\author{
Ayuba Pantu \\ IAIN Sultan Amai Gorontalo \\ Email: ayubapantu@yahoo.co.id
}

\begin{abstract}
This study aims to discover and describe how the Arabic influence on the development of the Indonesian language, which focused on the influence of the vocabulary, the influence of the Arabic alphabet and its influences on Indonesian syntax, as well as to discover how changes are absorbed Arabic vocabulary into Indonesian. The method used in this study is a literature review using the technique of content analysis, which is a research technique for making inferences that can be replicable, and valid the data by looking at the context. Sources of data in this study are the books relating to the object of research, among Indonesian Dictionary and other books. The results showed that the effect of Indonesian Arabic is big enough. This can be seen in the uptake of the Arabic word which ranks third after Dutch and English 1, 495 words. In addition, the use of Arabic script in Indonesian, which until now still many books, both Islamic religious books, Arabic books, tales, literature, written in Arabic alphabet Malay. Arabic influence on Indonesian syntax can be seen in books or Qur'an translations. The words of the absorption Arabic generally undergo changes in shape, as adapted to the Indonesian grammar or phonemes. It also changes the meaning, although the numbers are limited.
\end{abstract}

Penelitian ini bertujuan untuk menemukan dan menggambarkan bagaimana pengaruh bahasa Arab terhadap bahasa Indonesia, yang difokuskan pada pengaruh kosakata, pengaruh aksara Arab, dan pengaruh sintaksis Arab terhadap bahasa Indonesia, serta untuk menemukan dan menggambarkan bagaimana perubahan kosakata Arab yang diserap ke dalam bahasa Indonesia. Metode yang digunakan dalam penelitian ini adalah telaah pustaka dengan menggunakan teknik analisis isi (content analysis), yakni teknik penelitian untuk membuat inferensi-inferensi yang dapat ditiru (replicable), dan sahih 
data dengan memerhatikan konteksnya. Sumber data dalam penelitian ini adalah buku-buku atau tulisan-tulisan yang berkaitan dengan objek penelitian, antara lain Kamus Bahasa Indonesia serta buku-buku lain. Hasil penelitian menunjukkan bahwa pengaruh bahasa Arab terhadap bahasa Indonesia cukup besar. Hal ini dapat dilihat pada kata serapan dari bahasa Arab yang menduduki urutan ketiga setelah bahasa Belanda dan bahasa Inggris yakni 1.495 kata. Selain itu, penggunaan aksara Arab pada bahasa Indonesia, yang sampai saat ini masih banyak ditemukan buku-buku, baik buku-buku agama Islam, buku-buku bahasa Arab, hikayat-hikayat, sastra, yang ditulis dengan menggunakan aksara Arab Melayu. Pengaruh sintaksis Arab terhadap bahasa Indonesia dapat dilihat pada kitab-kitab atau buku-buku terjemahan al Quran. Kata-kata serapan dari bahasa Arab umumnya mengalami perubahan bentuk, karena disesuaikan dengan kaedah atau fonem bahasa Indonesia. Selain itu juga mengalami perubahan makna, meskipun jumlahnya terbatas.

Keywords: Arabic Influence, Arabic vocabulary changes.

\section{Pendahuluan}

Bahasa adalah alat komunikasi, bukanlah sesuatu yang statis. Bahasa tunduk pada hukum perubahan, dan karena itu senantiasa mengalami perkembangan seirama dengan perkembangan masyarakat. Para ahli linguistik berpendapat bahwa tidak ada bahasa yang murni di dunia ini. Oleh karena itu bahasa-bahasa dapat saling mempengaruhi satu dengan yang lain dalam satu atau dua arah. Meminjam kata dari bahasa lain bukan merupakan sebuah fenomena baru. Hal ini disebabkan oleh tiga faktor, yaitu faktor letak geografis yang berdekatan, faktor kekuasaan, dan faktor kebutuhan (Bakalla, 1990: 80).

Letak geografis yang berdekatan sangat memudahkan bahasa-bahasa saling mempengaruhi atau saling meminjam. Ini dapat dilihat pada masyarakat multilingual. Contohnya Arab dan Persia yang letak geografisnya berdekatan sehingga kedua bahasa tersebut saling mempengaruhi. Jawa dan Sunda yang letak geografisnya berdekatan dan berada pada satu pulau (pulau Jawa) menyebabkan kedua bahasa tersebut saling mempengaruhi. Demikian pula bahasa-bahasa masyarakat Bugis, Makasar dan Gorontalo yang berada di pulau Sulawesi saling mempengaruhi dan saling meminjam.

Faktor kekuasaan, misalnya kekuasaan militer atau ekspansi ke negaranegara lain seperti Belanda, Spanyol, dan Portugis, menyebabkan bahasa-bahasa penguasa tersebut menyebar di beberapa negara. Kerajaan Islam pada masa lalu pernah menguasai beberapa bagian dunia seperti Persia, India, Afrika dan 
Eropa, menyebabkan bahasa Arab mempengaruhi bahasa-bahasa di negara/ wilayah tersebut. Bangsa Belanda yang pernah menjajah Indonesia dalam waktu yang cukup lama, mengakibatkan bahasa Indonesia banyak dipengaruhi oleh bahasa tersebut. Begitu juga bangsa Portugis dan Inggris meskipun tidak lama menduduki wilayah Nusantara sebagaimana bangsa Belanda, namun bahasa mereka ikut mempengaruhi bahasa Indonesia. Ini dapat dilihat pada kata-kata serapan yang berasal dari bahasa Inggris jumlahnya cukup banyak. Menurut hasil penelitian bahwa kata serapan dari bahasa Belanda 3.280 kata, Inggris 1.610 kata, dan Portugis 131 kata (Jumariam, 1996: 9).

Faktor kebutuhan, misalnya proses modernisasi telah mempengaruhi seluruh dunia dengan berbagai cara. Kata-kata dari bahasa Eropa misalnya bahasa Inggris dan Perancis telah banyak mempengaruhi berbagai bahasa di dunia. Demikian pula halnya dengan bahasa Arab sebagai pembawa kebudayaan Islam, telah mempengaruhi bahasa-bahasa muslim di seluruh dunia. Ini dapat dilihat pada penggunaan kata-kata dan ungkapan bahasa Arab dalam doa atau ucapan salam dalam kehidupan sehari-hari.

Selain ketiga faktor tersebut, juga faktor sosial, kebudayaan, politik mapun agama sangat mempengaruhi perkembangan suatu bahasa. Bahasa Inggris berkembang pesat dan mempengaruhi bahasa-bahasa lain di dunia, karena faktor sosial, kebudayaan maupun politik. Demikian pula halnya bahasa Perancis, Jerman, Belanda dan lain-lain. Dalam sosiolinguistik ada sebuah ketentuan mutlak yang menganjurkan prinsip kontak bahasa yaitu setiap ada kontak kebudayaan dalam bentuk apapun, maka disini harus ada kontak linguistik sebagai hasilnya. Setelah itu bahasa akan menjadi sistem komunikasi manusia dan kata-kata dan ide-ide dari satu bahasa dapat tersebar melalui waktu dan tempat dengan cara tersendiri (Bakalla, 1990: 79).

Bahasa Indonesia yang mulanya berasal dari bahasa Melayu berkembang terus sesuai dengan perkembangan pemikiran penuturnya. Perkembangan bahasa Indonesia juga tidak lepas dari kontak kebudayaan dengan bangsabangsa lain seperti Belanda, Inggris, Portugis, Cina, Tamil dan Arab. Hal inilah yang menyebabkan bahasa Indonesia banyak dipengaruhi oleh bahasabahsa asing tersebut.

Sejak berkembangnya agama Islam di Nusantara ini pada abad ke-13 sampai saat ini dapat dilihat bahwa bahasa Arab telah turut membina dan mengembangkan bahasa Indonesia. Dengan kata lain, agama Islam yang dibawa oleh orang-orang Arab, menyebabkan bahasa Arab ikut mempengaruhi bahasa Indonesia. Pengaruh bahasa Arab terhadap bahasa Indonesia dapat 
dilihat pada banyaknya kata-kata pinjaman bahasa Indonesia yang berasal dari bahasa Arab terutama kata-kata atau ungkapan yang berkaitan dengan agama Islam. Hasil penelitian menunjukkan bahwa kata serapan dari bahasa Arab menduduki urutan ketiga setelah bahasa Belanda dan bahasa Inggris yakni 1.495 kata (Jumariam, 1996: 9). Kata- kata serapan dari bahasa Arab tidak hanya yang berkaitan dengan agama Islam, tetapi banyak juga serapan sebagai kata umum, seperti kursi, kitab, mistar, daftar, kertas, kalimat, ilmu, syarat, dewan majlis, hewan, jasad dan lain-lain. Kata-kata serapan tersebut banyak yang sudah mengalami perubahan bentuk karena penyesuaian dengan kaidah bahasa Indonesia, dan ada juga yang tidak mengalami perubahan bentuk. Selain perubahan bentuk, kata-kata serapan dari bahasa Arab ada yang mengalami perubahan atau pergeseran makna, bahkan ada pula yang memiliki makna yang berbeda, meskipun kedua-duanya berasal dari bahasa Arab. Contoh: kata berkat dan berkah, filsafat dan falsafah, amanah dan amanat.

Selain kosakata, pengaruh bahasa Arab terhadap bahasa Indonesia juga dapat dilihat pada aksara Arab yang digunakan pada bahasa Indonesia maupun bahasa daerah. Sampai saat ini masih banyak dijumpai tulisan-tulisan, buku-buku, baik buku agama, hikayat maupun sastra yang ditulis dengan menggunakan aksara (huruf) Arab yang dikenal dengan Arab-Melayu atau Arab-Jawi (Pegon). Termasuk juga bahasa-bahasa daerah baik yang memiliki aksara tersendiri maupun yang tidak memiliki aksara tersendiri, menggunakan aksara Arab dalam naskah-naskah mereka. Husen Abas mengemukakan: Pada awalnya bahasa Melayu menggunakan huruf Latin, tetapi ketika agama Islam masuk pada abad ke 13, maka sejak itu bahasa Melayu ditulis dengan menggunakan huruf Arab serta memasukkan unsur-unsur Islam melalui kata-kata Arab (Abas, 1996: 159). Pengaruh bahasa Arab terhadap bahasa Indonesia juga dapat dilihat pada sintaksis, meskipun hal ini terbatas pada terjemahan Al-Quran dalam bahasa Indonesia (Badudu, 1979: 14).

\section{Tinjauan Pustaka}

Para linguis sependapat bahwa bahasa Arab termasuk rumpun bahasa Semit, dan induk bahasa Semit adalah Proto-Semitika, yang oleh sebagian besar para ahli menganggap bahwa tempat lahirnya Proto-Semitika adalah Arab (Bakalla, 1990: 1). Sebagian para ahli membagi bahasa-bahasa Semit kepada dua bagian, yaitu (1) bahasa-bahasa Semit utara, terdiri dari bahasa Akadia, bahasa Assyro-Babilonia, bahasa Kan'an (Ibrani dan Fenisia), dan 
bahasa-bahasa Aramaia, (2) bahasa-bahasa Semit selatan, terdiri dari bahasa Arab, bahasa Yunani Purba dan bahasa-bahasa Ethiopia-Semit ( A. Akrom Malibary, 1976: 30). Sementara itu ada yang membagi bahasa Semit kepada bahasa-bahasa timur dan bahasa-bahasa barat. Bahasa-bahasa timur meliputi bahasa-bahasa Asyiria-Babilonia atau Akadiah, dan bahasa-bahasa barat terdiri dari Aramiyah, Kan'aniyah dan 'Arabiyah. Bahasa Arab sendiri terbagi kepada Arab selatan yang terdiri dari Ma'iniyah, Sabaiyah, Hadramiyah, Qatbaniyah, dan Habsyiyah, dan bahasa Arab utara yang terdiri dari Arab Bidah yang meliputi bahasa-bahasa Safawiyah, Samudiyah, dan Lihyaniyah, dan Arab Baqiyah yang meliputi bahasa Tamim dan Hijaz (Abdul Mu'in, 2004: 20). Gray dalam Bakalla mengatakan bahwa bahasa Arab merupakan bahasa yang paling muda di antara beberapa bahasa Semit, dan dianggap sebagai bahasa Semit paling primitif yang masih ada. Selain itu bahasa Arab merupakan bahasa yang paling kaya dalam literatur linguistiknya (Bakalla, 1990: 4). Ini dapat dilihat pada muculnya linguis linguis terkenal seperti Sibawaihi dan Al-Kisa'i yang diakui oleh kalangan linguis barat sebagai pelopor linguistik.

Bahasa Babilonia-Assiria yang merupakan cabang Semitika adalah bahasa yang sudah mati, dan kemudian digantikan oleh bahasa Aramaika sebelum permulaan tahun Masehi. Selama 1000 tahun (dari sekitar tahun 300 SM sampai sekitar tahun 650 SM) bahasa Aramaika ini digunakan sebagai bahasa resmi dan tulis yang penting di Timur Dekat, dan pengaruhnya besar pada sistem-sistem penulisan di Asia. Pada gilirannya, bahasa Aramaika digantikan oleh bahasa Arab. Penyebaran bahasa Arab, yang catatan paling awalnya adalah prasasti dari tahun $328 \mathrm{M}$, disebabkan oleh penaklukan-penaklukan orang-orang Arab yang beragama Islam sejak abad ke-7 M. Selama berabadabad bahasa Arab dipakai sebagai bahasa suci, sastra, dan resmi agama Islam (Bloomfield, 1995: 65). Para ahli sependapat bahwa peristiwa penting dalam sejarah perkembangan bahasa Arab adalah datangnya Islam dan tersebarnya sampai meluas ke daerah-daerah dari Asia Tengah sampai Afrika Barat. Semakin besar jumlah penduduk Islam, semakin meluas pengaruh bahasa ini sampai pada kehidupan kalangan orang-orang awam. Karena didorong oleh jiwa dan semangat keagamaan, pemeluk-pemeluk Islam mempunyai kecintaan membaca al Quran, baik untuk ibadah dengan tilawat (bacaan) al Quran itu semata atau untuk memahami isi al Quran dan menggali ajaran-ajaran Islam. Dari sinilah mulai terjalin hubungan bahasa Arab dengan agama Islam, sehingga membawa akibat yang jauh sekali bagi masa depan bahasa Arab yang kemudian menjadi bahasa keagamaan dan kebudayaan bagi dunia Islam. 
Pada masa Abbasiyah yang merupakan masa puncak keemasan Islam, bahasa Arab menempati dan memegang peranan penting dalam memelihara dan mengembangkan pelbagai macam ilmu pengetahuan dan filsafat Yunani. Pada masa ini dilakukan penerjemahan buku-buku ilmu pengetahuan dan filsafat Yunani ke dalam bahasa Arab. Buku-buku yang diterjemahkan antara lain buku-buku filsafat karangan Socrates, Plato dan Galinius serta buku-buku ilmu logika (Mantiq) dan ilmu alam karya Aristoteles. Akan tetapi perlu dicatat bahwa pada masa Abbasiyah (pertengahan abad III H) bahasa Arab percakapan mengalami kemerosotan akibat pengaruh bahasa-bahasa non Arab.

Sejak berhubungan dengan dunia luar, bahasa Arab telah meminjam beratus-ratus kata, dan hal ini akan memperkaya dan melengkapi bahasa Arab. Contoh kata-kata pinjaman dalam bahasa Arab (bahasa Arab Makkah).

$\begin{array}{lll}\text { Batatis } & \text { Italia } & \text { : patata, kentang } \\ \text { Makarona } & \text { Italia } & \text { : makaroni } \\ \text { Bantalon } & \text { Italia } & \text { : pantaloni, celana panjang } \\ \text { Baranda } & \text { Italia } & \text { : veranda, beranda } \\ \text { Bufeh } & \text { Perancis } & \text { : bufet, bupet } \\ \text { Kulonya } & \text { Perancis } & \text { : cologne, minyak kolonya } \\ \text { Batrol } & \text { Inggris } & \text { : petrol, minyak } \\ \text { Banzin } & \text { Inggris } & \text { : benzine, bensin } \\ \text { Sandarwits } & \text { Inggris } & \text { : sandarwich (Bakalla, 1990: 91). }\end{array}$

Gambaran ini menunjukkan bahawa bahasa Arab adalah bahasa yang fleksibel dan mempunyai kekuatan untuk menyesuaikan diri dengan perkembangan dan kebutuhan zaman moderen.

Memasuki abad ke-20 bahasa Arab berhasil menduduki tempat yang bergengsi diantara bahasa-bahasa dunia. Terbukti dengan diterimanya secara resmi sebagai salah satu bahasa organisasi dunia seperti PBB pada tahun 1973. Dengan demikian bahasa Arab sudah sejajar dengan bahasa-bahasa internasional lain yaitu bahasa Inggris, Prancis, Spanyol, Rusia, dan Cina. Keberhasilan tersebut disebabkan antara lain jumlah penduduk yang menggunakan bahasa Arab cukup banyak, dan negara-negara Arab telah memiliki pengaruh dalam perekonomian dunia.

Karena bahasa Arab sangat berperan dalam penyebaran ilmu pengetahuan, maka bahasa Arab juga ikut berpengaruh terhadap bahasa-bahasa lain di dunia, baik bahasa di Asia, Afrika maupun Eropa. Ini dapat dilihat pada kata-kata pinjaman (serapan) dari bahasa Arab yang masuk pada bahasa-bahasa tersebut. 
Contoh: mosque (Inggris) dari bahasa Arab (masjid), rice (Inggris) bahasa Arab ruzz (beras), alkuhul (Arab), alcohol. Kata amir (Arab), almirante (Spanyol), almirante (Portugis), ammiraglio (Italia), admiral (Perancis), admiral (Inggris). Makhzan (Arab), almacen (Spanyol), armazen (Portugis), magazzino (Italia), magazin (Perancis), magazine (Inggris). Menurut para ahli telah ditemukan sekitar 2000 akar kata dalam bahasa Inggris, dua pertiga darinya sudah tidak dipakai lagi, dan kira-kira dua pertiga dari sisanya masih dipergunakan dalam bahasa Inggris (Bakalla, 1990: 82).

\section{Tujuan Penelitian}

1. Untuk menemukan dan menggambarkan bagaimana pengaruh kosakata Arab terhadap bahasa Indonesia,

2. Untuk menemukan dan menggambarkan bagaimana pengaruh aksara Arab terhadap bahasa Indonesia,

3. Untuk menemukan dan menggambarkan bagaimana pengaruh sintaksis Arab terhadap bahasa Indonesia.

4. Untuk menemukan dan menggambarkan bagaimana perubahan kosakata Arab yang diserap ke dalam bahasa Indonesia.

\section{Metode Penelitian}

Penelitian ini adalah penelitian pustaka (library research) yang bersifat kualitatif-deskriptif, yaitu penelitian yang memfokuskan pada literatur yang menjadi objek kajian. Karena penelitian ini adalah kajian pustaka, maka metode yang digunakan dalam penelitian ini adalah telaah pustaka dengan menggunakan teknik analisis isi (content analysis). Analisis Isi (Content Analysis) adalah teknik penelitian untuk membuat inferensi-inferensi yang dapat ditiru (replicable), dan sahih data dengan memerhatikan konteksnya.

Sumber data dalam penelitian ini adalah buku-buku atau tulisan-tulisan yang berkaitan dengan objek penelitian, antara lain Kamus Bahasa Indonesia serta buku-buku lain.

\section{Pembahasan}

Pengaruh bahasa Arab terhadap bahasa Indonesia dapat dilihat pada banyaknya kosakata Arab yang sudah diserap ke dalam bahasa Indonesia, penggunaan aksara Arab baik pada bahasa Indonesia maupun bahasa daerah, serta terjemahan al Quran yang dipengaruhi oleh sintaksis bahasa Arab. 


\section{Kata Serapan}

Sebagimana telah dikemukakan bahwa kata serapan dari bahasa Arab menduduki urutan ketiga setelah bahasa Belanda dan bahasa Inggris yakni 1.495 kata. Hal ini berbeda dengan penelitian Sudarno, yakni terdapat 2.394 kata yang berasal dari bahasa Arab. Ia mengakui sulit untuk menentukan wujud dan jumlah yang pasti mengenai kata- kata bahasa Indonesia yang berasal dari bahasa Arab. Hal tersebut disebabkan oleh perbedaan sumber, dalam hal ini kamus atau buku-buku yang membicarakan etimologi, asal-usul kata. Salah satu sumber menyebutkan bahwa suatu kata berasal dari bahasa Arab, tetapi sumber lain menyatakan bahwa kata tersebut bukan berasal dari bahasa Arab, melainkan dari bahasa asing lainnya, atau malahan kata tersebut dinyatakan sebagai bahasa Indonesia asli (Sudarno, 1990: 18-21). Perbedaan yang cukup besar ini disamping disebabkan oleh perbedaan sumber (kamus), juga kosakata yang menurut penelitian Sudarno termasuk kata serapan dari bahasa Arab, tapi belakangan tidak dipakai lagi dalam perbendaharaan kosakata Indonesia. Kosa kata serapan tersebut banyak yang sudah mengalami perubahan, baik perubahan bentuk maupun arti.

\section{Perubahan bentuk}

Perubahan kata serapan dari bahasa Arab terjadi karena disesuaikan dengan fonem bahasa Indonesia. Perubahan yang dimaksud disini adalah penggantian, penghilangan, dan penambahan. Penggantian terjadi karena beberapa fonem konsonan bahasa Arab yang tidak terdapat dalam bahasa Indonesia, seperti:

Contoh penggantian fonem konsonan:

Bahasa Arab

مثال (misl)

(bas)

ثلاثاء $\quad$ (sulasa')

شكر

(sabr)

(ikhlas)

(khusus)

(hafadz)

(khabr)

(khayal)

(khiyanat)
Bahasa Indonesia

misal

bahas

Selasa

sukur

sabar

ikhlas

khusus

hapal

kabar

hayal

hianat 


\begin{tabular}{|c|c|c|}
\hline ضرورة & (dharurat) & darurat \\
\hline رضى & $(\operatorname{rid} z)$ & rela/redha \\
\hline فرض & $(\operatorname{fard} z)$ & perlu/fardhu \\
\hline فكر & $(f i k r)$ & pikir \\
\hline ضمين & $(d z a \min )$ & jamin \\
\hline قرطاس & (qirtos) & kertas \\
\hline ظاهر & (dzahir) & lahir \\
\hline ظليم & (dzalim) & (zalim) \\
\hline ذ ذكر & $(D z i k r)$ & zikir/jikir \\
\hline عقل & ('aqal) & akal \\
\hline معنى & $(m a ' n a)$ & makna \\
\hline اعلان & (i’lan) & iklan \\
\hline غائب & (ghaib) & gaib \\
\hline
\end{tabular}

Dari contoh-contoh di atas jelas bahwa fonem Arab yang tidak terdapat dalam bahasa Indonesia diganti dengan fonem bahasa Indonesia. Fonem ث/ ts/, ش ص ص /sy/sh/diganti dengan fonem /s/, baik di awal, di tengah maupun di akhir. Fonem $\dot{\tau} / \mathrm{kh} /$ diganti dengan $/ \mathrm{k} /$ atau /h/, fonem ف /f/ diganti dengan /p/, fonem b/th/ diganti dengan/t/, fonem / dz/ diganti dengan /l/ atau /z/, fonem ض/dh/ diganti dengan /d/ atau $/ \mathrm{j} /$, fonem $\dot{\varepsilon} / \mathrm{gh} /$ diganti dengan $/ \mathrm{g} /$, fonem $\mathrm{j} / \mathrm{d} /$ diganti dengan $/ \mathrm{z} / \mathrm{dan}$ $/ \mathrm{j} /$, fonem $\tau / \mathrm{h} /$ diganti dengan $/ \mathrm{h} /$, dan fonem $\mathrm{a} / \mathrm{q} /$ diganti dengan $/ \mathrm{k} /$. Kata ضمين menjadi jamin dalam bahasa Indonesia merupakan bentuk kata itu satu-satunya. Artinya kata tersebut tidak mempunyai bentuk kembaran (Sudarno, 1990: 132).

Fonem ع/_/ dihilangkan ketika berharakat fathah, kasrah atau dhummah, عقل dan diucapkan seperti fonem vokal Indonesia /a/, /i/ /u/, misalnya akal, ععاء doa, علماء ilmu, عله ulama. Kalau berharakat sukun, dilambangkan dengan huruf k, contoh: معنى (makna), معلوم (maklum). Pengucapan fonem /k/ pada kata-kata makna, maklum, seperti bunyi hamzah. Berbeda dengan iklan pengucapannya seperti $/ \mathrm{k} /$ pada kata bahasa Indonesia.

Penulisan kata yang memiliki fonem $\varepsilon / .$. / ini pada masa ejaan Van Ophijsen menggunakan apostrof ('), seperti kata ma'na, ma'lum, ta'jub, kemudian pada ejaan Soewandi diganti dengan $/ \mathrm{k} /$, tapi pengucapannya berbeda dengan /k/ pengganti fonem ق ق مقصود (maksud), مقبول (makbul), dan lain-lain. Begitu juga hamzah yang berharakat sukun dilambangkan dengan huruf /k/ seperti مؤمن mukmin, مأموم makmum. Dengan demikian 
huruf $\mathrm{k}$ dalam kata bahasa Indonesia melambangkan fonem $\mathrm{a} / \mathrm{q} /$, fonem $\varepsilon$ /.'/, dan huruf hamzah (s).

Pergantian fonem konsonan tidak hanya pada fonem yang tidak terdapat dalam bahasa Indonesia, tetapi juga pada fonem yang ada dalam bahasa Indonesia, dan diganti dengan fonem yang tidak dalam bahasa Arab. Contoh: kata انكار (inkar) menjadi ingkar, مكن (mumkin) menjadi mungkin.

Berbeda dengan fonem konsonan, fonem vokal bahasa Arab semuanya terdapat dalam bahasa Indonesia, namun kenyataannya ada yang diganti dengan fonem yang tidak terdapat dalam bahasa Arab yakni fonem /e/ dan fonem $/ \mathrm{o} /$.

Contoh penggantian fonem vokal/i/, /a/ dengan /e/:

Bahasa Arab

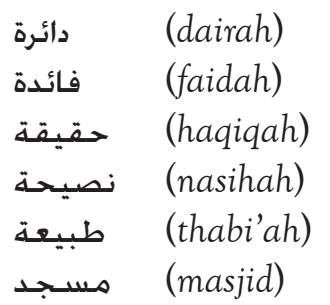

ترجمة (tarjamah)

(sadaqah)

شـركة (syarkah)

بركة (barkah)

جماعة (jama'ah)

(tafakkar)
Bahasa Indonesia

daerah

faedah

hakekat

nasehat

tabeat

mesjid

terjemah

sedekah

serikat

berkat/berkah

jamaah/jemaat

tepekur

Contoh penggantian fonem vokal rangkap /ai/ dengan /e/, dan/au/ dengan $/ \mathrm{o} /$ :

\begin{tabular}{|c|c|c|}
\hline 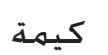 & (kaimah) & kemah \\
\hline شيطان & (syaithan) & setan \\
\hline 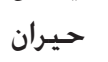 & (hairan) & heran \\
\hline 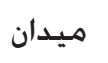 & (maidan) & medan \\
\hline شيخ & (syaikh) & syekh \\
\hline تو & (taubah) & tobat \\
\hline \multicolumn{3}{|c|}{ Contoh penggantian fonem vokal /u/ dengan /o/: } \\
\hline 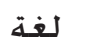 & (lughah) & logat \\
\hline قر & (qurban) & rorbar \\
\hline . & (sual) & $\mathrm{al}$ \\
\hline
\end{tabular}




$\begin{array}{lll}\text { حور } & (\text { ruh }) & \text { roh } \\ \text { دعاء } & \left(d u^{\prime} u\right) & \text { doa }\end{array}$

Pemakaian vokal/u/ dan /o/ dijumpai juga dalam kosakata Indonesia, misalnya kata juang-joang, lobang-lubang, gua-goa, surga-sorga, rubuh-roboh, kukuh-kokoh. Vokal /o/ kemudian diganti dengan /u/ ( joang menjadi juang, goa - gua, lobang - lubang, sorga - surga, roboh - rubuh, kokoh - kukuh). Khusus kata kurban dan korban, kedua-duanya digunakan dalam konteks yang berbeda. Korban berarti 'menderita akibat suatu kejadian', sedang kurban bermakna 'persembahan kepada Tuhan' (daging atau hewan kurban).

Penghilangan terdapat pada fonem suprasegmental (maddah), tasdid (fonem rangkap), dan huruf yaa (ي) serta hamzah (s) jika terdapat pada akhir kata. Contoh: muslimin - muslimun, mahir - mahir, karim - karim. Fonem rangkap: sunnah - sunat, haqq - hak, hajj-haji, kulliyah-kuliah, jinn - jin, ihhah - sehat, mayyit - mayat, tammat - tamat, quwwah - kuat. Huruf yaa: kursiyyu - kursi, nabiyyu - nabi, 'Aliyyu - Ali, islamiyyu - islami. Huruf hamzah: دعاء (du'u) menjadi doa, علماء ('ulamu)- ulama, زناء (zinu)-zina, رياء (riyu)-riya. Namun ada juga huruf hamzah yang diganti dengan huruf h, yaitu pada kata وباء (wabu) menjadi wabah.

Penghilangan juga terdapat pada vokal di tengah kata, dan penghilangan suku kata yaitu suku kata awal, contoh:

Bahasa Arab

ورقـــ (waraqat)

(nafaqat)

(itsnain)

Vokal /a/ pada tengah kata waraqat dan nafaqat dihilangkan, menjadi warkat dan nafkah. Kata itsnain mula-mula menjadi isenin, kemudian vokal atau suku kata awalnya dihilangkan sehingga menjadi senin (Sudarno, 1990: 137).

Selain penggantian dan penghilangan, juga terjadi penambahan pada kata-kata serapan, yaitu penambahan fonem khususnya fonem vokal, dan penambahan suku kata, dan hal ini merupakan gejala yang lazim dalam proses penyerapan kata dari bahasa Arab oleh bahasa Indonesia, contoh:

Bahasa Arab

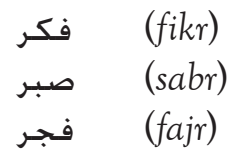

Bahasa Indonesia

warkat

nafkah

Senin 


\begin{tabular}{|c|c|c|}
\hline قدر & $(q a d r)$ & kadar \\
\hline عقل & ('aql) & akal \\
\hline فقــ & (fiqh) & fiqih \\
\hline شـرط & (syart) & syarat \\
\hline خبر & (khabr) & kabar \\
\hline صبح & (subh) & subuh \\
\hline عصر & ('asr) & asar \\
\hline ظه & $(d u h r)$ & zuhur \\
\hline
\end{tabular}

Sebenarnya proses penambahan vokal ini mula-mula menghilangkan fonem atau tanda syakal akhir kata yakni tanwin (fikrun menjadi fikr, sabrun menjadi sabr, fajrun menjadi fajr, subhun menjadi subh), kemudian huruf kedua diberi syakal sebagaimana syakal huruf pertama sehingga menjadi fikir, sabar, fajar, dan subuh. Penambahan vokal ini tidak berlaku bagi semua kata yang sejenis dengan itu, karena terdapat beberapa kata yang tidak mengalami penambahan, seperti kata 'ilm, qalb, tetap ilmu, kalbu bukan ilim atau kalab.

Suatu hal yang menarik dari kata serapan bahasa Arab ialah fonem yang ditulis dengan huruf taa marbutah (a) dan selalu menduduki posisi akhir kata. Pengucapannya sama dengan fonem $/ \mathrm{h} /$ kalau dibaca waqaf, dan sama dengan /t/ kalau berharakat. Kata-kata yang memiliki fonem ini ketika diserap ke dalam bahasa Indonesia dapat dikelompokkan menjadi tiga. Pertama, sama dengan pengucapan bahasa Arab yakni fonem /h/, seperti jazirah, madrasah, fitnah, wilayah. Kedua, tetap fonem/t/, seperti kalimat, maklumat, akhirat, kiamat. Ketiga, mempunyai dua bentuk yakni fonem /h/ dan /t/, dan kedua bentuk tersebut ada yang tidak jelas perbedaannya, seperti: ibadah/ibadat, jamaah/jemaat, falsafah/filsafat, berkah/berkat, amanah/amanat (Sudarno, 1990: 75-76). Selain tiga kelompok itu, ada juga kata dari bahasa Arab yang memiliki fonem tersebut (taa marbutah) namun dihilangkan, contoh: kata menjadi mistar bukan mistarah atau mistarat.

Satu hal menarik lagi ialah ketika kata-kata yang memiliki taa marbutah ini mendapat imbuhan (awalan dan akhiran), dapat dikelompokkan menjadi dua. Pertama, huruf h berubah menjadi $t$, contoh: musyawarah - permusyawaratan. Kedua, huruf h atau huruf t tidak diganti, contoh: wilayah - perwilayahan, mufakat - permufakatan, serikat - perserikatan. Ada juga kata yang tidak memiliki taa marbutah, yakni "zina", ketika diserap ke dalam bahasa Indonesia dan mendapat imbuhan -an menjadi "perzinahan", seharusnya "perzinaan". 


\section{Perubahan Makna}

Kata-kata serapan dari bahasa Arab ada yang berubah maknanya baik secara keseluruhan maupun berubah dalam arti pengkhususan atau penyempitan. Contoh: kuliah, artinya fakultas, dalam bahasa Indonesia diartikan pelajaran atau belajar di perguruan tinggi. Kalimat, artinya kata, sedang dalam bahasa Indonesia adalah susunan kata-kata. Jumlah artinya kalimat, dalam bahasa Indonesia adalah banyaknya sesuatu yang dikumpulkan menjadi satu. (jumlah dalam bahasa Arab berarti kalimat dalam bahasa Indonesia). Mualim artinya guru/pengajar, dalam bahasa Indonesia adalah juru mudi kapal. Madrasah artinya sekolah, dalam bahasa Indonesia khusus sekolah agama. Ulama (bentuk jamak dari alim) artinya orang-orang berilmu, dalam bahasa Indonesia khusus yang ahli di bidang agama Islam, dan dipakai dalam bentuk tunggal. Contoh: Buya Hamka adalah seorang ulama terkemuka.

\section{Sistem Penulisan (Aksara)}

Pengaruh bahasa Arab terhadap bahasa Indonesia juga pada sistem penulisan (aksara). Sebelum datangnya Islam, aksara yang digunakan adalah aksara Latin, tetapi ketika agama Islam masuk pada abad ke 13, maka sejak itu aksara yang digunakan adalah aksara Arab yang dikenal dengan Arab Melayu atau Arab Jawi (Pegon). Pigeaud mengatakan, teks Jawa yang ditulis dengan aksara Arab disebut teks Pegon artinya 'sesuatu yang berkesan menyimpang' (Pudjiastuti, 2006: 45). Sampai saat ini masih banyak dijumpai buku-buku baik buku agama Islam, sastra, hikayat, bahkan buku bahasa Arab yang ditulis dengan menggunakan aksara Arab Melayu. Contoh:

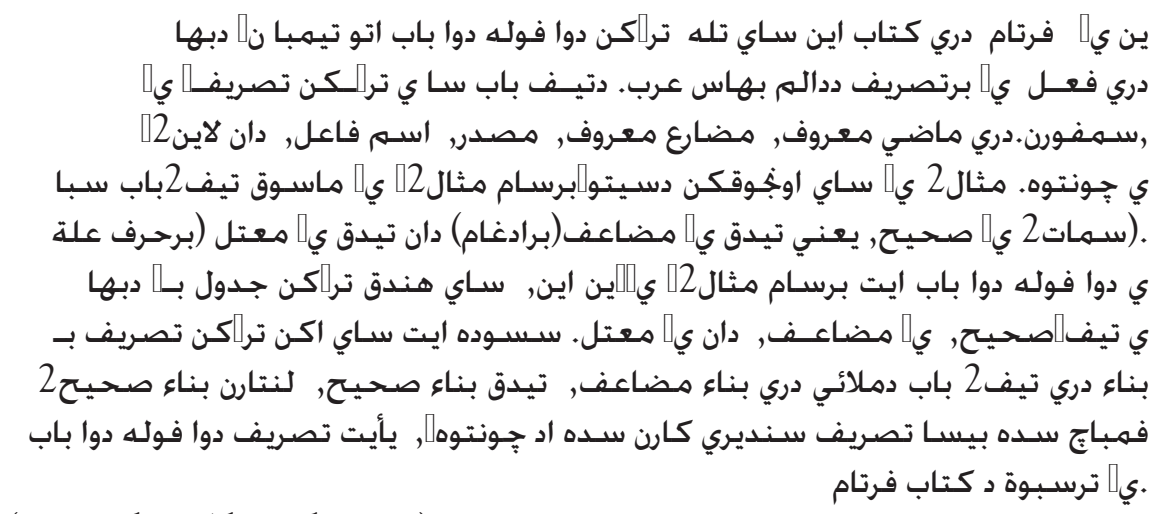

(Hasan bin Ahmad, tt: 1)

"Di bahagian yang pertama dari kitab ini saya telah terangkan dua puluh dua 
bab atau timbangan dari fi'il yang bertashrif di dalam bahasa Arab. Di tiap bab saya terangkan tashrifnya yang sempurna. Dari madhi ma'ruf, mudhari' ma'ruf, mashdar, isim fa'il, dan lain-lainnya, bersama misal2 yang masuk tiap2 bab sebagai contoh. Misal2 yang saya unjukkan di situ semata2 yang sahih, yakni tidak yang mudha'af (beridgam) dan tidak yang mu'tal (berharf 'illat).Di bahagian ini, saya hendak terangkan judul bagi dua puluh dua bab itu bersama misal2nya yang sahih, yang mudha'af, dan yang mu'tal. Sesudah itu, saya akan terangkan tashrif bagi tiap2 bina dari tiap2 bab dimulai dari bina mudha'af, tidak bina sahih, lantaran bina sahih pembaca sudah bias tashrif sendiri karena sudah ada contohnya, yaitu tashrif dua puluh dua bab yang tersebut di kitab pertama”.

Penggunaan aksara Arab ini bukan hanya pada bahasa Indonesia, tapi juga pada bahasa-bahasa daerah baik yang memiliki aksara tersendiri seperti Jawa, Sunda, Makasar, atau daerah yang tidak memiliki aksara seperti Gorontalo. Ini dapat dilihat pada naskah-naskah daerah setempat baik naskah keagamaan, sastra, cerita-cerita maupun sejarah daerah itu sendiri.

Contoh naskah mi'raj dalam bahasa Gorontalo:

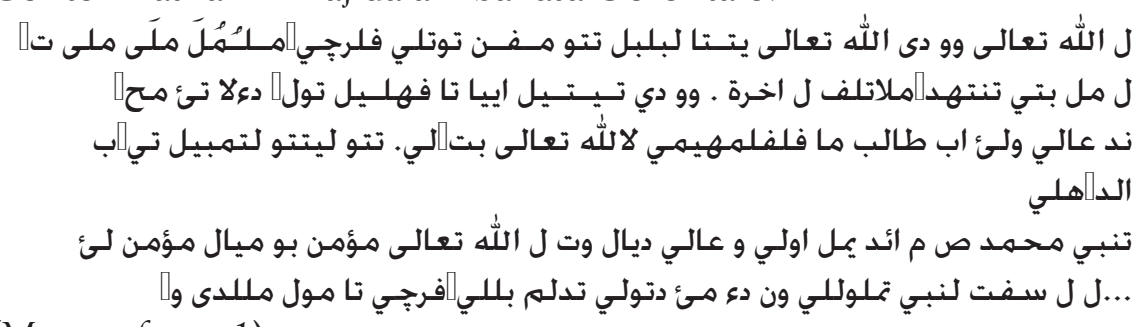

(Monoarfa, tt: 1)

"Molumula mola moli tanggulo Allahu ta'ala wawu de Allahu ta'ala yito ta laba-laba lotutu moponu towato lio pilaracaya mola to lipu lo ahirati. Wawu de tiyo-tiyolo eya tapohileyala tulungi doula tou mohungguli mola botiya tontahudu baginda Ali walai Abi Thalib ma pilopolamahiyomai lo Allahu ta'ala batangaliyo. Tutuliotu lotombilu tio ilodungohelio tonabi Muhammad saw 'o'odiyamola uwalio wu Ali diyalu wato lo Alaah ta'ala mukmini buwa mealo mukmini la'I paracaya ta mowali molulade wungguli lo sifati lo nabi to mulololio wonu deu mao dutuwolio to delomo belelio..."

Penggunaan aksara Arab dalam bahasa Gorontalo, tidak jauh beda dengan penggunaan dalam bahasa Indonesia. Hal ini dapat dilihat pada lambang beberapa fonem atau huruf yang tidak terdapat dalam bahasa Arab seperti / $\mathrm{ng} /$, /c/, /ny/, dan /g/. Hanya saja dalam bahasa Gorontalo, huruf $\bullet / \mathrm{h} /$

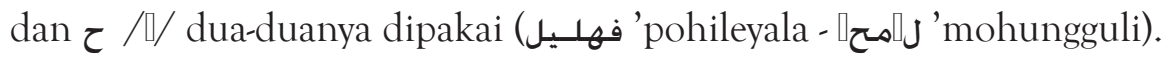




\section{Sintaksis}

Pengaruh sintaksis Arab terhadap bahasa Indonesia dapat dilihat pada kitab-kitab atau buku-buku terjemahan al Quran. Ayat-ayat al Quran umumnya diawali dengan huruf waw ( (gyang diterjemahkan dengan dan, sehingga terjemahnya juga dan, padahal dan dalam bahasa Indonesia adalah kata sambung yang menghubungkan dua kata atau klausa (kalimat). Dalam bahasa Arab, waw ( (gtidak selamanya berfungsi sebagai a'thaf (penghubung). Selain waw, juga huruf fa (ف) yang berarti maka, sehingga terjemahan al Quran banyak dijumpai kata dan serta maka pada awal kalimat.

Contoh, "Maka Allah merasakan kepada mereka kehinaan pada kehidupan dunia. Dan sesungguhnya azab pada hari akhirat lebih besar kalau mereka mengetahui. (QS az Zumar: 26).

"Dan sungguh jika kamu bertanya kepada mereka, "Siapakah yang menciptakan langit dan bumi?" niscaya mereka menjawab, "Allah". Katakanlah, "Maka terangkanlah kepadaku tentang apa yang kamu seru selain Allah, jika Allah hendak mendatangkan kemudharatan kepadaku, apakah berhala-berhalamu itu dapat menghilangkan kemudaratan itu, atau jika Allah hendak memberi rahmat kepadaku, apakah mereka dapat menahan rahmat-Nya?...(QS az zumar: 38).

Kata serapan dari bahasa Arab umumnya mengalami perubahan bentuk karena disesuaikan dengan kaedah atau fonem bahasa Indonesia. Ini tidak hanya terdapat pada bahasa Indonesia, tetapi juga pada bahasa-bahasa lain. Hal ini dianggap lumrah, dan ahli linguistik historis menggolongkannya sebagai tipe adaptasi, yakni bentuk bahasa asing diubah agar cocok dengan kebiasaan-kebiasaan fonetis dasar bahasanya. Contoh: sugar mungkin 'arkara: Sanskerta, sucre sykr Prancis, zucchero 'tsukkero Italia, Zucker 'tsuker Jerman, 'sakkharon Yunani, 'saxar Rusia, azucar a'ukar Spanyol, adalah pinjaman dari bentuk Arab dengan partikel as sukkar "the sugar" sama saja dengan algebra, alcohol, alchemy yang mengandung partikel Arab al "the". Hal ini disebabkan oleh substitusi dan adaptasi yang terjadi dengan kondisi-kondisi yang sangat berbeda-beda dalam bahasa-bahasa yang meminjam dan yang meminjamkan (Bloomfiled, 1933 : 431-443).

Meskipun banyak fonem Arab yang tidak terdapat dalam bahasa Indonesia, namun ada beberapa fonem yang sudah familiar bagi orang Indonesia khususnya orang Islam, dan tidak sulit melafalkan fonem-fonem tersebut, yakni fonem خ/kh/, ش/sy/,j/z/, ف ض ف/dh/, contoh: 


\begin{tabular}{|c|c|c|c|}
\hline خاص & khas & اخبر & akhir \\
\hline فتنة & fitnah & فجر & fajar \\
\hline زكاة & zakat & جزيرة & jazirah \\
\hline مشاورة & musyawarah & مشهور & masyhur \\
\hline شـاعر & syair & مشاركة & masyarakat \\
\hline شهداء & syuhada & شرط & syarat \\
\hline اخلاص & ikhlas & خصوص & khusus \\
\hline مخلوق & makhluk & اخلاق & akhlak \\
\hline ختان & khitan & خالق & khalik \\
\hline اخرة & akhirat & رضى & redha \\
\hline
\end{tabular}

(Kata شـرط syarat, tidak bisa diganti dengan sarat, sebab dalam bahasa Indonesia kata sarat berarti penuh).

Kata-kata serapan dari bahasa Arab ini termasuk unik, karena ada kata-kata serapan yang tetap dipertahankan atau dipelihara meskipun sudah ada bentuk serapannya, sehingga dua-duanya dipakai dalam konteks yang berbeda. Misalnya: kata redha, fardhu, kurban, yang biasanya digunakan dalam konteks yang berkaitan dengan agama, sedang bentuk serapannya yakni rela, perlu, korban, digunakan bukan pada konteks agama. Contoh:

"Keredhaan Allah tergantung pada keredhaan orang tua, Orang tuanya sudah merelakan kepergiannya, Salat jenazah hukumnya fardhu 'ain, Praktek salat jenazah perlu diterapkan sejak SD, Penyembelihan hewan kurban dilaksanakan di halaman mesjid, Korban gunung meletus sudah mencapai ratusan orang."

Kata-kata yang berkaitan dengan agama umumnya masih dipertahankan, seperti, zakat, zikir, fitrah, ijab kabul, akhirat, sunat, tahajud, tayamum, wudhu', nama-nama bulan (Muharram, Safar, Rajab, Ramadhan), bacaan/ gerakan salat (fatihah, ruku', sujud, i'tidal), dan lain-lain.

Kata ibadah dan ibadat maknanya sama, begitu juga jamaah dan jemaat, hanya saja kata ibadat dan jemaat biasanya dipakai untuk kegiatan agama tertentu, misalnya agama Nasrani, sedangkan kata ibadah dan jamaah umumnya dipakai pada kegiatan agama Islam. Kata falsafah dan filsafat memiliki makna yang berbeda, contoh: "Pancasila sebagai falsafah negara", "Filsafat 
sebagai ilmu”. Kata berkah dan berkat juga memiliki makna yang berbeda, demikian pula kata amanah dan amanat. Contoh: Berkat ketekunannya ia berhasil meraih apa yang ia cita-citakan. Dalam mencari rezki hendaklah dengan cara yang halal agar memperoleh berkah dari Allah SWT. Jabatan merupakan amanah, Amanat pembina upacara.

Penghilangan, terdapat pada maddah (fonem suprasegmental) dan tasdid vocal rangkap), karena bahasa Indonesia tidak mengenal fonem suprasegmental dan tasdid, kecuali pada kalimat, yang disebut jeda. Contoh: Ibu saya pergi ke pasar, kalau jedanya pada kata ibu, berarti yang pergi ke pasar adalah saya, tetapi kalau jedanya pada kata saya, berarti yang pergi ke pasar adalah ibu. Bahasa Indonesia juga tidak mengenal tasdid (vocal rangkap), kecuali namanama orang yang umumnya diambil dari bahasa Arab, seperti Amiruddin, Syamsuddin, Khairuddin, Baharuddin, dan lain-lain.

Aksara Arab yang digunakan pada bahasa Indonesia atau bahasa daerah, seperti halnya tulisan bahasa Arab, umumnya tidak berharakat. Selain itu, ada beberapa fonem Indonesia yang tidak ada lambangnya dalam aksara Arab, namun hal ini tidak menimbulkan kesulitan dalam melambangkan fonem-fonem tersebut. Fonem /ng/, dilambangkan dengan huruf ghain titik tiga, fonem /ny/ dilambangkan dengan huruf nun titik tiga, fonem /c/ dengan huruf jim titik tiga (飞), dan /g/ dengan kaf titik di atas. Pada bahasa Gorontalo, fonem vokal/o/ dilambangkan dengan huruf hamzah di bagian atas (), dan vokal /e/ di bagian bawah ().

Meskipun bahasa Indonesia tidak mengenal maddah (fonem suprasegmental), ايت- دري -اين - سـاي : namun penulisannya tetap menggunakan maddah seperti bahkan ada yang hanya satu suku kata, seperti: دان berbeda dengan kata tidak memakai maddah. Kata اوبجوقكن (unjukkan) memakai dua maddah sekaligus (و), sementara تركن (terangkan) tidak memakai maddah. Selain itu, hambat

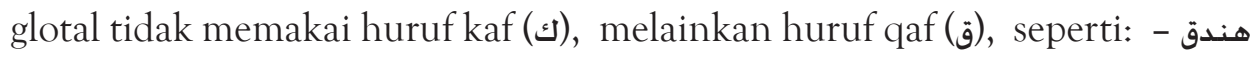
تيدق- ماسـوق / padahal fonem / a/ ketika diserap ke dalam bahasa Indonesia diganti dengan $/ \mathrm{k} /$, seperti : mutlak, makbul, huruf t pada akhir kata menggunakan taa marbutah (ترسبوة).

\section{Simpulan dan Saran}

Bahasa Arab memiliki pengaruh yang cukup besar terhadap perkembangan bahasa Indonesia. Pengaruh tersebut dapat dilihat pada banyaknya kosakata Arab yang diserap ke dalam bahasa Indonesia, penggunaan sistem penulisan (aksara), dan sintaksis. Kosa kata Arab yang diserap ke dalam bahasa Indonesia 
umumnya mengalami perubahan bentuk karena disamping penyesuaian dengan kaidah bahasa Indonesia, juga terdapat beberapa fonem Arab yang tidak terdapat dalam bahasa Indonesia. Selain perubahan bentuk, juga perubahan makna meskipun jumlahnya tidak banyak. Meskipun terdapat beberapa fonem Arab yang tidak dalam bahasa Indonesia, namun ada juga beberapa fonem Arab yang dapat diterima dalam bahasa Indonesia. Penggunaan aksara Arab pada sistem penulisan tidak hanya terbatas pada bahasa Indonesia, tapi juga pada bahasa daerah. Pengaruh sintaksis Arab terhadap bahasa Indonesia hanya dapat ditemukan pada buku-buku terjemahan al Quran.

Karena masih banyak ditemukan buku-buku, hikayat, dan sastra, baik dalam bahasa Indonesia maupun bahasa daerah yang ditulis dengan menggunakan aksara Arab (Arab Melayu atau Pegon), dan tidak banyak masyarakat yang mampu membacanya, maka perlu memberikan pendidikan atau latihan kepada siswa atau mahasiswa terutama jurusan bahasa tentang cara membaca teks Arab Melayu (Arab Pegon).

\section{Daftar Pustaka}

Abas, Husen. 1996. Perkembangan Ejaan Bahasa Indonesia. Dalam Soenjono Dardjowidjojo (Ed.). Bahasa Nasional Kita dari Sumpah Pemuda ke Pesta Emas Kemerdekaan. Ed.. Bandung: ITB.

Ahmad, Hasan.tt. Kitabut Tashrif. Bangil. Raihan.

Badudu, J.S. 1979. Pelik-Pelik Bahasa Indonesia. Bandung: Pustaka Prima.

Bakalla, M. H. 1984. Pengantar Penelitian Studi Bahasa Arab. Terjemahan oleh Males Sutiasumarga 1990. Jakarta: Hardjuna Dwitunggal.

Bloomfield, Leonard. 1995. Bahasa. Terjemahan oleh I. Sutikno. Jakarta. PT Gramedia: Pustaka Utama.

Departemen Agama RI. 1980. Al Quran dan Terjemahnya. Jakarta: Proyek Pengadaan Kitab Suci Al Quran.

Departemen Pendidikan dan Kebudayaan, Pusat Pembinaan dan Pengembangan Bahasa. 2010. Kamus Besar Bahasa Indonesia. Ed ke-3. Jakarta: Balai Pustaka.

Jumariam dan Almanar, Alma E. 1996. Senarai Kata Serapan Dalam Bahasa Indonesia. Jakarta: Depdikbud. 
Malibary, A. Akrom dan Basyar, Achmad. 1976. Pedoman Pengajaran Bahasa Arab pada Perguruan Tinggi Agama Islam IAIN. Jakarta: Depag RI.

Mu'in, Abdul. 2004. Analisis Kontrastif Bahasa Arab Ë Bahasa Indonesia. Jakarta: Pustaka Al Husna Baru.

Monoarfa. tt. Isra' Mi'raj Nabi Muhammad.ttp.

Pudjiastuti, Titik.2006. Naskah dan Studi Naskah. Bogor: Akademia.

Sudarno. 1990. Kata Serapan dari Bahasa Indonesia. Jakarta: Arikha Media Cipta. 